\section{The National Scientific Lending Library}

RePLying to a question in the House of Commons on April 2, the Parliamentary Secretary to the Ministry of Works, as representing the Lord President of the Council, said that the Department of Scientific and Industrial Research had now formed a unit to implement the National Scientific Lending Library project and this unit would move into temporary accommodation in London early in April. The collection of foreign scientific and technological literature had commenced, and it was hoped that full lending library facilities would develop at a later stage. Erection of a suitable building for the National Reference Library of Science was under consideration in connexion with a project for building a new Patent Office.

\section{Sherrington Centenary}

THe centenary of the birth of Sir Charles Scott sherrington, a founder and main architect of the physiology of the nervous system, is celebrated this year. The Royal Society of Medicine, wishing to pay tribute to his life and work, proposes to raise a fund towards a Sherrington Lecture, for the furtherance of knowledge on the nervous system, to be delivered from time to time in the Society's rooms in London. Many will wish to contribute: both those who were his friends, pupils and colleagues, and those, more numerous, who, as patients, doctors and scientists, have benefited indirectly from his work. Donations should be made payable to the Secretary, Royal Society of Medicine, 1 Wimpole Street, London, W.1, and cheques crossed 'Sherrington Memorial'. The appeal issued by the Royal Society of Medicine bears the signatures of : Sir Russell Brain (president of the Royal College of Physicians); Sir Lindor Brown (foreign secretary of the Physiological Society); Prof. J. Fulton (Stirling professor of the history of medicine, Yale University); Mr. W. R. Henderson (president of the Society of British Neurological Surgeons); Sir Cyril Hinshelwood (president of the Royal Society); Prof. E. G. T'. Liddell (Waynflete professor of physiology, University of Oxford); $\mathrm{Mr}$. D. W. C. Northfield (president of the Section of Neurology, Royal Society of Medicine) ; Sir Clement Price Ihcmas (president of the Royal Society of Medicine); Sir (harles Symonds (president of the Asscciation of British Neurologists); Sir Francis Walshe (chairman of the Sherrington Memorial Committee, Royal Society of Medicine).

\section{Indian Journal of Mycological Research}

THE first issue of the Indian Journal of Mycological Research-the official organ of the Mycological Society of India - has just appeared (obtainable from the Department of Botany, University College of Science, Calcutta) under the editorship of Dr. S. N. Banerjee. In a foreword, the president of the Society, Prof. S. R. Bose, makes a point of emphasizing the popular ignorance of the fungi in India and expresses hope that this state of affairs may be remedied by the work of his Society. 'Ihe reader will note, perhaps with some surprise but with understanding, that the first three papers in this initial volume consist of work carried out in Great Britain under distinguished exponents in the field of plant pathology. However, this is after all not so very strange, since science is international and since India is such a large and varied territory that problems of plant pathology in Europe have their counterpart in very similar prob- lems in India. Thus, in the present issue, we may note that a disease of Norway spruce in Scotland is matched by a contribution on fungal diseases of conifers in the Himalaya; while a paper on the effects of age and storage conditions on the susceptibility of certain vegetables to attrck by tissuerotting fungi will find its application just as much in some of the provinces of India as in Western Europe. The Journal is well produced, with abundant line and photographic illustrations of good quality. Mycologists and pathologists in Britain will no doubt follow the progress of the new Journal with sympathetic interest.

\section{Orientation of Churches}

From an account given by a captain in the Parliamentary Army in the seventeenth century, it would appear that when a church was to be erected the builders carefully noted the exact point where the Sun rose on the morning of the feast of the church's patron saint and then orientated the building accordingly. Again, Wordsworth in 1823 says that the deviations of the axes of church buildings from a true east-west line were due to the fact that they pointed to the sunrise on the day of their patronal festivals. More recently, this explanation was rejected by C. J. P. Cave and others. But now fresh investigations seem to confirm the old tradition. The Rev. Hugh Benson, in an article in the Antiquaries Journal for July-October 1956, points out that a number of readings made by Cave did not take account of the fact that nowadays the true horizon is frequently concealed by buildings or other obstructions, and it is necessary to wait for the Sun to appear above them. Now, especially in winter, as soon as the Sun has risen above the horizon it appears to move southwards in its journey across the heavens, and so, should there have been any appreciable interval between its actual rising above the horizon and its appearance to the watcher, the east-west axis of the building would be several degrees out of the true. A great many of the churches in Oxfordshire have been re-examined, and a large proportion are in fact correctly aligned. In the absence of any tradition of precise measurement in the Middle Ages, it is not to be expected that every case should con. form perfectly, but the fact that so many churches are exactly orientated is significant. 'The acceptance of the Julian calendar introduced a further complication. The occurrence of crooked naves may be largely explained by the fact that any rebuilding of the chancel would involve a reorientation of the east-west axis owing to the changed position of the sunrise according to the new calendar. But all crooked naves cannot be thus interpreted. What about the odd orientation of the nave and west tower of St. Benèt's Church, Cambridge?

Benson's article is a very good corrective of the assertions made by Cave, Eeles and others, and it would seem certain that in a large number of cases the orientation of churches did have a connexion with the sunrise on the day of their patronal festivals.

\section{Pacific Science Board: Report for 1955}

Among the operations during 1955 which are noted in the ninth annual report of the Pacific Science Board (pp. 58. Washington, D.C. : National Academy of Sciences-National Research Council, 1956) is the co-ordinated investigation of Micronesian anthropology, for which the posts of district anthropologist 